\title{
GENRE BASED APPROACH TO TEACHING NARRATIVE WRITING
}

\author{
Zurdianto \\ Guru SMPN4 Pekanbaru, Propinsi Riau
}

\begin{abstract}
This study aims at investigating the process of writing narrative text at lower secondary level of education (SMPN 4 Pekanbaru, Riau Province). The researcher, assisted by an English teacher as his collaborator, employed classroom action research to observe teaching and learning process. The study was conducted within two Cycles in which each Cycle comprised modeling, joint construction, and independent construction. Four instruments consisting of observation sheet, field notes, interview, and test were used to collect the data in Cycle 1. Five instruments consisting of observation sheet, field notes, interview, test, and questionnaire were used to collect the data in Cycle 2. The finding shows that three steps of writing narrative text to enhance the students' learning atmosphere and improve the students' writing achievement included (1) the students determined the important information from the text; (2) the students shared their ideas about their works with their friends; and (3) the students presented the texts in the class and discussed them with their classmates. Genre-based approach has been proved to enhance joyful learning atmosphere and improve the students' learning writing achievement in classification text. Another finding is all participants customarily went through the basic phases of the writing process of narrative text: prewriting, drafting, revising and most of the them only know the terms like generic structure of the text. Besides, Interview in Cycle 1 revealed that the students felt comfortable, happy, and enjoyed learning writing using genre-based approach. Interview in Cycle 2 revealed that genre-based approach was comfortable, helpful to get outline of information, and an easy way to comprehend the text. Questionnaire indicated out of 35 students, 20 students' responses were "strongly agree" and 15 responses were "agree" for the benefit of genre-based approach implementation. The finding of the students' writing achievement showed that out of 35 students, 19 students got the score above 60 in Cycle 1; meanwhile, all students got the score above 60 in Cycle 2.
\end{abstract}

Key Words: Genre, narative, wriring, teaching

\section{A. Introduction}

Changes and innovations in English education in Indonesia has been most likely reflected in the changes of curriculum. Suyanto (2001) argues that the curriculum changes are driven by (i) some innovation in theories about the teaching of English and (ii) the failures of implementing one after another curriculum. One of the aspects of the curriculum that is subjected to change is teaching approach. As an illustration, in the 1994 curriculum, it was stated that the students were required to be able to communicate in English using the four English language skills (listening, speaking, reading, and writing). The teaching approach to be 
adopted was "the meaningful approach", which was basically the communicative approach. The teachers were expected to integrate the four language skills, the grammar, and the vocabulary creatively, so that the teaching objectives could be reached in the time available.

Based on the government's
review and feedback from the practitioners and scholars, the 1994 curriculum was changed. The change was also motivated by the influence of political movements, one of which was the movement towards autonomous provision for the provinces and regions. The new curriculum had to cater for, and be suitable for, the needs of each province and region and, at the same time, it also had a national standard. Because of that, the new 2004 curriculum was designed on the basis of some basic competencies the students had to master. The new curriculum sought to fill what was lacking in the previous ones. In the new curriculum it was stated that the graduates were expected to have both a language competency and a general competency. For the language competency, the students were expected to be able to understand English texts, to communicate in English and to use English for enjoyment (Pusat Kurikulum-Balitbang Departement Pendidikan Nasional, 2001). In the new curriculum, in accordance with the underlying language principles and the description of teaching and learning activities, even though it is not explicitly stated, a genre-based approach is adopted.

English teachers are supposed to be able to teach their students both language components and language skills. One of the language skills they are supposed to teach is writing skill. Despite the emphasis of teaching on reading comprehension and the limited time provided for writing activities, teachers should provide students with opportunities to develop their writing skill. Writing makes a special contribution to the way people think. A piece of writing composes meanings. Alwasilah (2001: 15) in his longitudinal study of writing process involving 29 graduate students revealed that 62.1 percent of the respondents believe that Indonesian education-from elementary to college-has failed to provide them with writing skills. Facts and ideas are put to make something new, whether in a letter home, in a college essay, or in a report at work. In writing, meaning is created in which sentences have special relationships to each other. Some sentences are general and some specific; some expand a point and others qualify it; some define and others illustrate (Axelrod, 1988:2).

Writing makes another important contribution to learning. Writing helps us to find and establish our own network of information and ideas, as it is always a composing of new meaning. It allows us to bring together and connect new and old ideas. Writing enables us to clarify and deepen our understanding of a new concept and to find ways to relate it to other ideas within a discipline. Thus, writing test, clarifies, and extends understanding (Axelrod,1988:2). Learning to write is like learning to speak, involves the gradual mastery of a complex series of language conventions for constructing meanings at different levels of organizations for constructing meanings at different levels of organizations, including letter formation, spelling, syntax, discourse and genre (Fox, 1993). He further states that the learner has to learn how to use, control, and understand the writing process across a wide series of genres and contexts. 
There are various reasons for significant writing. Firstly, a wonderful idea which is not expressed clearly and logically, will not have benefit to anyone. Secondly, the act of writing is a thinking and learning act. Learning to write means learning to think. Thirdly, educated people need writing ability. Finally, from psycholinguistics viewpoint, low reading interest among people at all age levels and educational levels may result from the fact that writings-books, literature and other references-are not interesting, out of readers' interest, and do not attract readers to read (Rasyid,1999:2). Those writings are poorly written and badly organized.

One of the most challenging tasks English teachers face nowadays is making their students write different genres as required by the new competence-based curriculum (CBC). To carry out this task, teachers need to have clear ideas regarding what micro and macro skills students need to develop so that they can develop essays of different types. This means that writing activities are no longer geared around what to write (topics), but how to write (skills of writing). This is by no means saying that topics are not important; they are still important, but they are used as a means of acquiring the writing skills. Topics are always needed, but high school students do not need to address topics that are not very relevant to their immediate needs. With limited time allotment, teachers need to focus on the key issue, that is, teach and show students how to write.

It is important to note that at SMP (Lower Secondary Level of Education) students are not expected to write in written style of English. For example, if they can write a narrative text using "spoken English written down", that would be acceptable as long as they can produce simple grammatical sentences, well organized text or create a unified whole.

\section{B. Theoretical Base}

This study delineates some aspects to do with the theoretical base. The researcher based his study on the draft of the 2004 English Curriculum, curriculum cycle of the Genre-based Approach proposed by Callaghan and Rothery 1989; Hammond 1990; and Callaghan, Knapp, and Noble 1993. The proposed theories are utmost importance to be discussed because they can support the process of data analysis relating to the research problems.

The curriculum that had been implemented at the school where this research was conducted was still the draft of the 2004 English curriculum. Meanwhile, the KTSP was about to be used by English teacher at the school. In that curriculum, a Narrative text is taught to students of Junior High Schools, in semester two of the class nine. The following is the quotation of that curriculum.

\section{Figure 1. The Draft of the 2004} English Curriculum

$\begin{array}{ll}\text { School level } & : \text { Lower Secondary } \\ \text { Level of Education } & \\ \text { Year } & : \text { IX }\end{array}$

Standard competence : To communicate both written and spoken using relevant and accurate linguistics variation in interactional discourses and/or in monologue, mainly in Narratives, descriptive, recount, procedure and report.

In relation to the theory of curriculum cycle, the researcher presented One of the popular models of genre approaches is the Curriculum Cycle or Wheel model. There are some variations of this curriculum cycle model (e.g Callaghan and Rothery 1989; Hammond 1990; and Callaghan, Knapp, and Noble 1993). Despite the variations, this wheel model consists of three main stages that include modeling, joint 
construction and independent construction.

At the first stage, modelling, refers to a stage where the genre in question is presented and analysed by the teacher with the students in various activities. Modeling is an important aspect of the genre approach. At Basic Competences this stage the social purpose, text 3.4. WRITING To understand the nuance of meanings and structure and the steps of language developing rhetoric in features of genre are investigated (Callaghan,

Knapp, and Noble, 1993).

The modelling stage focused on two main aspects, building the written texts, particularly Narratives, descriptives, and recount.

students' background knowledge about the topic and introducing the students to a model of genre to be learned (Feez and Joyce, 1998; Hammond, 1990; Paltridge 2001).

The second stage is called joint construction. Within the curriculum cycle this is a stage where the students construct a text together and teachers gradually reduce their contribution to the text construction (Feez and Joyce, 1998; Callaghan et al., 1993). At this stage the issue of scaffolding is central and thus both "design-in scaffolding" and "point of need scaffolding" were offered (Hammond, 2001:34-37). According to Feez and Joyce (1998), and Hammond (1990) the joint construction can be performed in two ways, within whole class and group writing activities. The whole class joint construction is intended to give handson experiences in putting ideas into writing, organising the ideas, and using appropriate language.

At the third stage, the independent construction, is a stage where the students construct their

Indicators $\quad$ Materials individual

texts. At this stage, support by the lecturer is reduced as the students are

encouraged to work independently (e.g. Gibbons, 2002;

Hammond, 2001). Even so, when necessary, they may seek for advice or suggestions to the teacher or Jakarta, 2003.

their peers. The students write their own text. For students with limited control over written language, explicit guidance in understanding purpose, schematic structure and the language features of a genre is needed before they can proceed to independent construction. At this stage the teacher and students have a shared language and knowledge with which to discuss the problems encounter in independent construction.

\subsection{Methodology}

The purpose of conducting this research is to increase the students' writing competence through the implementation of genre-based approach (GBA) at lower secondary school level of education at SMPN 4 Pekanbaru, Riau Province. Thus, the design of the study 
used for this research is classroom action research using curriculum cycle of GBA. Classroom action research is specially addressed for a teacher and a researcher. Moreover, Latief (2010:8182) states that the primary purpose of classroom action research is to increase the quality of teaching in a classroom. The view concerns with the position of the researcher as a teacher in a classroom. Classroom action research also aims at developing innovative learning strategy to aid students to enhance their learning achievement. This view relates to the position of the teacher as a researcher. Hence, this research design can be used for the teachers who have teaching problem in their

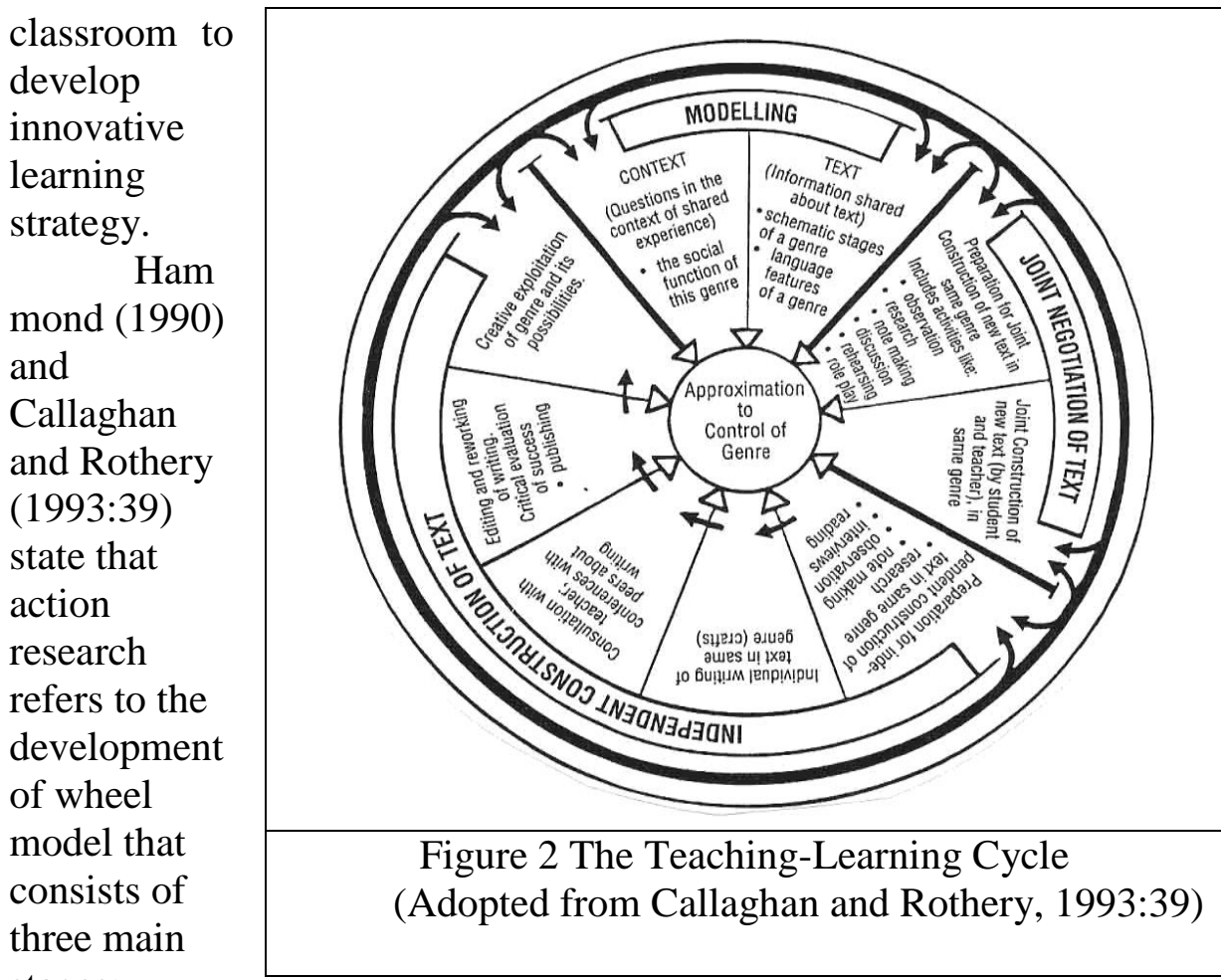

stages:

modeling, joint construction, and independent construction.

At the first stage, modeling, refers to a stage where the genre in question is presented and analysed by the teacher with the students in various activities. The students are introduced to model text (s) of a genre the students are supposed to learn. Through this way the students learn the concept of genre and the significant features of the genre. Reading the model text, the students investigate the social purpose, the schematic structure and language features of the genre (Callaghan et al, in Cope and Kalantzis, 1993; Christie, 1992; Gibbons, 2002; Martin, 1999). In the curriculum cycle of the genre-based approach, this stage comes before the joint construction. According to Hammond in Paltridge (2001), teachers, however, may also come back to modelling at any stage if it is necessary as the stages of a curriculum cycle are not necessarily fix in sequence.

The second stage is called joint construction. The whole class joint construction is intended to give handson

experiences in putting ideas into writing, organising the ideas, and using appropriate language. And, the application of group work aims to enable the students to work collaboratively in sharing and generating ideas, gathering and organising material, and offering peer review. The students gather and organise the information they need to write a text. In order to get information, they are required to do research and discussions whether through individual 
or group work activities. Here the teacher give guidance. "The teacher then acts as a scribe for the class and helps turn student ideas into an approximation of the genre" (Callaghan et al, 1993:182 in Cope and Kalantzis).

At the third stage, the independent construction, is a stage where the students construct their individual texts. At this stage the teacher and students have a shared language and knowledge with which to discuss the problems encounter in independent construction. Originally, the genre-based approach is intended to help students to develop their writing skills. Students are scaffolded as such that they can move gradually from speaking activities to writing activities. In the current high school curriculum implemented in Indonesia, however, the teaching cycles are divided into spoken written cycles. This may be intended to make it easier or the teachers to allocate the time and to put emphasis.

Meanwhile, regarding the instruments of data collection used in this study were questionnaire, observation, field note, test, and interview. These served to answer both of the addressed research questions. Questionnaire was distributed to students at the end of one Cycle of classroom action research. Latief (2010:151) states questionnaire is a written instrument which consists of a number of questions. The questionnaire is used for gathering the opinion from the respondents. Three scopes of questions in questionnaire in preliminary study are: (1) students' opinion about writing narrative text, (2) students' opinion about the teaching and learning activities in their class, and (3) students' opinion about genre-based approach to teaching and learning writing narrative text.
The observation was conducted in each meeting in the cycle of classroom action research. The observation describes behavior and interactions (Ary et al., 2006:474). The observation was used to monitor the students' interaction among them and students' interaction with their teacher in the teaching and learning writing process in the classroom. The observation activity was performed by the researcher and collaborator. The collaborator is one of the English teachers of SMPN 4 Pekanbaru, Riau Province. Fieldnote used was the reflections on method field note for each meeting to record students' learning interaction in the learning process (Bogdan \& Biklen, 2007: 123). The learning interaction consists of the interaction between students and students and the interaction between students and the teacher. Two aspects of field note that are recorded include: (1) the strength of the method in teaching and learning process and (2) the weakness of the method in teaching and learning process. A test was administered to students at the end of each Cycle. The test used in this study was writing a short story to measure the students' writing skill.

All the collected data were then analyzed by adopting the approach of descriptive analysis conducted by Cresswell (2012) consisting of collecting data, identifying, classifying, describing, and determining the problems of study.

\section{Findings}

\section{Teaching Cycle 1}

a. Teaching and Learning Activities regarding Writing Narrative Text

At the beginning of this research, the students felt doubtful about what text is. As indicated by the students' question "What is text, sir?" This might be 
happened due to the ineffectiveness of applying "Modeling cycles" in the teaching practice. Actually, the knowledge of text should have been taught to students in their first year, when they were studying "Narrative text". However, until this research was conducted, the students still had problem in the basic knowledge. Concerning writing a narrative text, actually it should have been taught to students before this research was conducted.

The data indicated that fundamental problems happened in the classroom activities. In short, precisely, there was no practicing writing in these three observations. Other possibility was from the modeling of the text, too. Respondent teachers gave modeling of the text to students by orally narrating the text to students. Moreover, this was supported by the admittance from the interviewees. There was no written model given to students as the students' source of information. However, the students looked seriously following the classes being conducted by them. The seriousness of students in following his/her teaching was proved by the students' raising questions. The questions addressed were among others: Can we use Simple Past in a narrative text?

In the opening activities, they asked the students to find and write generic structure of the narrative texts anything that came to their minds. This activity was divided into three rounds and each round took only 10-15 minutes. The students were grouped into pairs, and each pair served as opponent one to another. The students had to find and write as fast as they could without paying too much attention on their grammars. After each round, each opponent had to count his/her rivals' number of words.
At the first stage, modeling, refers to a stage where the genre in question was presented and analysed by the teacher with the students in various activities. Modeling is an important aspect of the genre approach. At this stage the social purpose, text structure and language features of genre were investigated. The modelling stage focused on two main aspects, building the students' background knowledge about the topic and introducing the students to a model of genre to be learned. The students were introduced to model text (s) of a genre the students were supposed to learn. Through this way the students learn the concept of genre and the significant features of the genre. Reading the model text, the students investigated the social purpose, the schematic structure and language features of the text.

The second stage was called joint construction. Within the teaching cycle this was a stage where the students constructed a text together and teachers gradually reduce their contribution to the text construction. They have been taught The joint construction of the text. It can be performed in two ways, within whole class and group writing activities. The whole class joint construction is intended to give hands-on experiences in putting ideas into writing, organising the ideas, and using appropriate language. And, the application of group work aims to enable the students to work collaboratively in sharing and generating ideas, gathering and organizing material, and offering peer review.

The students gather and organize the information they needed to write a narrative text. In order to get information, they were required to do research and discussions whether through individual or group work 
activities. Here the teachers gave guidance. "The teachers then acted as a scribe for the class and helped turn student ideas into an approximation of the text.

At the closing activities, respondent teachers have been done the third stage of teaching cycle, the independent construction, it was a stage where the students construct their individual texts. At this stage support by the teacher was reduced as the students are encouraged to work independently.

Even so, when necessary, students might seek for advice or suggestions to the teacher or their peers. The students wrote their own text. For students with limited control over written language, explicit guidance in understanding purpose, schematic structure and the language features of a genre is needed before they can proceed to independent construction. At this stage the teacher and students have a shared language and knowledge with which to discuss the problems encounter in independent construction. Therefore, it was very far from what the students expected or needed to have from this classroom process. Writing is a "process" (Alwasilah, 2005) and is the "training of thinking skills" (Gardener, 1995). Therefore, the most suitable teaching technique to writing is through practicing or exercising writing.

\section{b. The Students' Opinions and Expectation on Writing Narrative Text}

Regarding the students attitudes towards writing, the findings indicated that all students were pleased to write. This indicates that the teaching of writing gets a positive response from the students. This has something to do with the Modeling cycle's role in the teaching of a narrative text to students.
Two students stated undecided about writing. This means that some students will like writing, if they feel they are familiar with the issue (writing is a matter of pleasure: see Achard in Alwasilah, 2005). However, if the issue is strange to them, they turn to hate writing. This indicates that the role of building knowledge of the field in the teaching of writing, particularly a narrative text, is considered very helpful for enhancing the students' view about the issue. By doing so, it is expected that the students will be motivated in learning writing. And there was only one student stating that writing was unpleasant activities. It means that the student dislikes writing activities. RS\#5 said that writing needs sufficient vocabulary and good mastery of grammatical expressions. It means that the teaching of grammar is still considered important in learning English. Nevertheless, the findings had revealed that most of the participants still enjoyed writing activities.

The findings, as also indicated in the texts the students wrote, which will be discussed later in this chapter, displayed that the students have mastered the schematic structure of a narrative text. It means the students have mastered the generic coherence of the text (Eggins, 1994:87). However, they admitted that at the beginning, they did not know what to write in the preview and the stages of text. After several meetings, they gradually knew what to write in each stage and were able to use some linguistic features in the texts of narrative. This was the result of the teaching and learning processes conducted, as expressed in the following dialogue.

Interviewer: "In your opinion, can the teacher's explanation enhance your understanding about 


\author{
writing a narrative \\ text?" \\ Interviewee: "Yes, it can".
}

This dialogue shows that the teaching, particularly Modeling cycle, conducted by the teacher has resulted a good understanding of writing a narrative text for the students.. Nevertheless, the problems were they did not know how to develop arguments with evidence. This is actually natural since the teaching of writing is equal to the teaching of stimulating "creativity and productivity" (Gardener, 1995) in the students' life. Therefore, the teaching should be done explicitly and repeatedly. By doing so, the students will be accustomed to writing and by being accustomed to writing automatically, they will be able to "train their thinking skills" (Gardener, 1995:7 \& 9). This will in turn serve to build "carefulness in thinking and taking decision" (Emilia, 2006) for students.

Regarding the students' expectation, all of the participants of this research stated that writing activities in their school were very poor, as expressed to answer the question "How were the writing activities at your school?" RS\#1 and RS\#2: "rarely", RS\#3: "less active", RS\#4: "not very often done", RS\#5: "sometimes done", etc. Their responses indicate that writing was not priority at their school yet. Meanwhile, the draft of the 2004 English curriculum suggests that in Junior High schools the continuum from spoken language is changed into written language. In addition, two of the participants even claimed that English writing activities in their school were almost nil, as in "Probably, it can be said never" (RS\#1 and RS\#3).

Some students claimed that the source of this unexpected condition was from the teacher's side, as expressed to answer the question "From whose side do you think this problem originate?" RS\#1: "From the teacher's side", RS\#3: "Probably from the teacher". This indicates that teacher was not so active to teach writing. Therefore, students got problems when they were asked to write. This case is opinion by the expression from RS\#2 who claimed that the teacher lacked of motivation to teach writing.

Regarding the students' expectation about writing a narrative text, most of the participants only know the terms like generic structure of the text. However, when they were interviewed what they should write in each stage, most of them failed to express a proper answer, as expressed by RS\#1: Preview is the community's general point of view about the stages. Although the answer has contained the essence of preview, however it is still incorrect. According to Smith (1995:21), the preview is the giving of a flash so the readers understand what the discussion is about. Theoretically, although they have understood all stages in terms of name, they still failed to write a proper content to each of the stages. Averagely, five students failed to express the proper contents in each stage. There were only three students able to approach a proper answer. RS\#4: "The general point of view about the issue, so that we know what to put into arguments". RS\#5: "to describe generally two different opinions about the issue". This shows that some students have started to understand what to write in the Preview of Issue. In short, this was their gradual understanding towards writing a narrative text.

\section{Teaching Cycle 2}

a. Teaching and Learning Activities regarding Writing Narrative Text 
To develop students' competence in writing narrative texts, there are at least three key issues teachers need to address. The first issue is communicative purpose. Every time a student starts to write, s/he needs to be clear about why s/he writes. For example, s/he writes in order to entertain, to tell past events, to describe something and so on. Once the communicative purpose is determined, a student needs to deal with the second issue, that is, how to achieve the purpose. To have good knowledge of how successful writers achieve the same or similar communicative purpose, a student needs to have some ideas about some elements that characterize a particular genre and how those elements are organized. The third issue is identifying what sentence patterns, tenses, and other features that are often used in a particular genre. Armed with this knowledge, a teacher can plan activities such as group discussions, reading model passages, discussing sentence patterns including the tenses, all of which are geared around writing a text.

It is also found that all participants wrote a narrative text, s/he needed to understand that the communicative purpose of a narrative genre was to entertain the readers. In order to entertain the readers, a narrative genre was needed to have at least three elements: orientation, complication, and resolution. Linguistically, a narrative is often told in the past tense.

Procedural writing is one of the process narrative. It explains how something is done or how to do it (Axelrod, 1988:434 and Saraka, 1988:143). Saraka clearly provides that the emphasis is on the steps involved in the process. The presentation of ideas usually employs a logical step-by-step sequence. According to Feez and Joyce (1998:24), there are five stages to be followed in writing narratives, they are: Orientation, Complication, Evaluation, Resolution, Reorientation or Coda.

Teachers frame their teaching and learning activities in terms of presents the stages of teaching. The teaching and learning activities RT used the models of genre approaches. They consists of three main stages that include modeling, joint construction and independent construction.

At the first stage, modeling, refers to a stage where the genre in question was presented and analysed by the teacher with the students in various activities. Modeling is an important aspect of the genre approach. At this stage the social purpose, text structure and language features of genre were investigated. The modelling stage focused on two main aspects, building the students' background knowledge about the topic and introducing the students to a model of genre to be learned. The students were introduced to model text (s) of a genre the students were supposed to learn. Through this way the students learn the concept of genre and the significant features of the genre. Reading the model text, the students investigated the social purpose, the schematic structure and language features of the text.

The second stage was called joint construction. Within the teaching cycle this was a stage where the students constructed a text together and teachers gradually reduce their contribution to the text construction. RT have been taught The joint construction of the text. It can be performed in two ways, within whole class and group writing activities. The whole class joint construction is intended to give handson experiences in putting ideas into 
writing, organising the ideas, and using appropriate language. And, the application of group work aims to enable the students to work collaboratively in sharing and generating ideas, gathering and organizing material, and offering peer review.

The second finding is all participants customarily went through the basic phases of the writing process of narrative text: prewriting, drafting, revising. They showed the different stages in the production of a piece of writing narrative text. Some participants wrote topics that they knew about, meaning that the topics were something they knew and relatively familiar as they had direct experience with the topics. It relates to what Trimmer (1992:10) clarifies that whether we are responding to an assignment or creating one, we need to take certain steps to find a suitable subject. First, select a subject we know or can learn something about. The more we know about the subject, the more likely we are to make it our own, shaping it to our own perspective.

The students gather and organize the information they needed to write a narrative text. In order to get information, they were required to do research and discussions whether through individual or group work activities. Here the teachers gave guidance. "The teachers then acted as a scribe for the class and helped turn student ideas into an approximation of the text.

At the third stage, the independent construction, it was a stage where the students construct their individual texts. At this stage support by the teacher was reduced as the students are encouraged to work independently. Even so, when necessary, students might seek for advice or suggestions to the teacher or their peers. The students wrote their own text. For students with limited control over written language, explicit guidance in understanding purpose, schematic structure and the language features of a genre is needed before they can proceed to independent construction. At this stage the teacher and students have a shared language and knowledge with which to discuss the problems encounter in independent construction.

\section{b. Students' Opinions and Expectations on Writing Narrative Text}

The present study reveals several findings with regard to the teaching learning activities concerning writing narrative text. Related to the interview question number 4 , The first finding is indicated that the students were pleased to write. This indicates that the teaching of writing gets a positive response from the students. This has something to do with the Modeling cycle's role in the teaching of a narrative text to students. Two students stated undecided about writing. This means that some students will like writing, if they feel they are familiar with the issue (writing is a matter of pleasure: see Achard in Alwasilah, 2005). However, if the issue is strange to them, they turn to hate writing. This indicates that the role of building knowledge of the field in the teaching of writing, particularly a narrative text, is considered very helpful for enhancing the students' view about the issue.

By doing so, it is expected that the students will be motivated in learning writing. And there was only one student stating that writing was unpleasant activities. Students wrote a narrative text, s/he needed to understand that the communicative purpose of a narrative genre was to entertain the 
readers. In order to entertain the readers, a narrative genre was needed to have at least three elements: orientation, complication, and resolution. Linguistically, a narrative is often told in the past tense.

All participants discovered their initial topic of their writing through prewriting as it was a way to get started. All participants generated and developed ideas as they wrote, using their own strategies with certain principles: specificity, manageability, curiosity, significance, and familiarity. When the participants were given the task of selecting their own topic for an academic writing paper, it was essential for them to spend time thinking about and researching possibilities and options. In this study, the participants had selected topics that were restricted, interesting, familiar, significant, and manageable to write. In other words, they used certain principles as formulated by themselves based on each condition, those principles were specificity, manageability, curiosity, significance, and familiarity.

All participants selected topics which were narrowly defined, they began their writing assignment with topics that were so broad or general that they needed to be narrowed in scope. It was in line with what Trimmer (1992:10) suggests that select a subject we can restrict. The more we can restrict the subject, the more likely we are to control our investigation, identify vivid illustrations, and maintain a unified focus.

In relation to restrict the topic, Gibson (2002:61) states that finding a topic to write about can be frustrating that we have to narrow down the topic into a specific one. There's nothing wrong with starting out with a general topic, but we don't wait to stay with a general topic too long. Typically, the broader the topic, the more general paper will be. As well, most of participants tried to write on a subject which had interested in. They found it easier and interesting to put more time into their work. In relation to this, Trimmer (1992:10) states that an interesting subject need not be dazzling or spectacular, but it does need to capture our curiosity. If it bores us, it will surely bore our readers. We need to decide why a specific subject fascinates us and how we can make the subject more intriguing for the readers. Langan (1987:91) supports that whenever possible, the writers try to write on a subject which interests them, so it is easy to put more time to work.

The second finding is regarding the students' expectation about writing a narrative text, most of the participants only know the terms like generic structure of the text. However, when they were interviewed what they should write in each stage, most of them failed to express a proper answer, as expressed by RS\#1: Preview is the community's general point of view about the stages. Although the answer has contained the essence of preview, however it is still incorrect. According to Smith (1995:21), the preview is the giving of a flash so the readers understand what the discussion is about. Theoretically, although they have understood all stages in terms of name, they still failed to write a proper content to each of the stages. Averagely, five students failed to express the proper contents in each stage.

Although the process of writing narrative text is essentially idiosyncratic, writers usually work through a few basic phases. Parris (2002) classifies writing process as pre writing, drafting, revising, presenting. Meanwhile Murray (1980) distinguishes three stages in writing: rehearsing, drafting, and revising. According to 
Ronk (2003) there are five main steps labeled: pre writing, writing a first draft, sharing, revising into a second draft, and editing into a final draft. Even though they use different terms, the content, indeed, serves the same purpose.

Prewriting is any kind of activity that helps the writer determine what he or she will write about. Many things qualify as prewriting activities. Some of the most common are: making lists, conducting research, formal or informal reading, interviews, brainstorming, webbing, clustering, outlining, remembering, drawing, discussion, prewriting, notebook or journal writing, note taking. Hacker (2003:3) states that whatever technique the writers turn to, the goal is the same: to generate a wealth of ideas. At this early stage of the writing process, they should aim for quantity, not necessarily quality, of ideas. If an idea proves to be trivial, or too far, they can always throw it out later.

Drafting is what most people call 'writing' is where formal writing begins. Using prewriting materials as inspiration, the writer writes and writes and writes some more. He/she doesn't worry too much about mechanics or style or organization or anything other than getting everything down on paper as quickly and as easily as possible.

Like prewriting, in the drafting stage it is important that participants were given time and encouragement to engage in risk-free exploration of their subject matter. This is the best time to try things out. Strategies such as the following may facilitate the translating of ideas into first and successive drafts: fast or prewriting, personal letters, reflecting and questioning, conferencing, "writing-off" leads, mapping (Parris, 2001:7). It was in relation to what the participants did in this stage, they used some of those strategies such as writing drafts, conferencing, "writing-off" leads, mapping thoughts.

Most participants went through their writing process of narrative text in a recursive way; that is, they used a nonlinear approach to the writing process of the text. Some participants had to write drafts many times, printed, read, checked whether there were mistakes or not then added or deleted the information and rewrote it. In other words, they constantly reviewed and modified their texts as they wrote and often produced several drafts to achieve a finished product. This relates to what Emig (1971) in Parris (2001:2) confirms that writing is a messy process. It is not linear; it is recursive, "a loop rather than a straight line," where the writer writes, then plans or revises, and then writes again. Similarly, Gibson (2002:60) says that writing is recursive activity, a series of thought processes that are repeated a number of times, but not always sequentially: brainstorming, drafting, developing and organizing ideas, adjusting content and form to a specific audience's needs and expectations, revising, and editing.

All participants wrote a series of successive drafts, meaning that they wrote more than one draft. They always added or eliminated the ideas came to their mind after they completed and then read their drafts. According to Parris (2001:7), drafting is rarely completed in one sitting. The writers usually need to let the work sit for a bit and then write a series of successive drafts if they wish to produce polished compositions. Discussing drafts with others (including peers and teacher) can help move each of their drafts closer to the final version.

Moreover, she argues that in the same way that the processes of idea 
generation and revision are recursive and ongoing, responses-written and oral - to students writing by a variety of audiences are essential for successful writing. Students, teachers, and peers play important roles in the response process: student writers are continuously writing, reading, and revising their prose, for example, peers offer the social context within which response occurs; teachers identify certain competencies on the part of the learners and intervene appropriately in the process.

Most participants found the exchange of ideas at various points in the writing process helpful. Collaboration gave them the chance to bounce ideas around with other people - their classmates, close friend, instructors, for example. Most importantly, collaboration placed them in the position of articulating their ideas about their writing (Gibson, 2002:69). When developing their ideas, the participants looked for reactions and suggestions. All participants collaborated with their peer-talking about their ideas whenever the opportunity presented itself. Writing conference is a kind of collaborative activity in writing classes. Conferences can take numerous forms and the teacher does not always need to be directly involved. In fact, students should be encouraged to discuss their writing with their classmates. Students can meet with one or two classmates to ask for advice, share a piece of writing, or revise a composition.

Procedural problems covered many things; to mention some, overlapping ideas, trouble getting started, lack of ideas, selecting experts' ideas, lose sight of main focus, placing back-up sources, paraphrasing, summarizing, synthesizing, and so forth. All participants experienced such kind of problems. Most of the problems related to how the participants expressed their ideas down to the paper. It seemed that they lacked of technical skills in writing. They knew what needed to be said, but they could not figure out how to do it. Moon (1998:2) clarifies that like a beginner trying to build a house with only a hammer and saw and a pile of lumber, they have to work harder to accomplish the same structure. Writers can't go out and buy a new writing tool-there's no store that sells "a viewpoint transition chisel" or "a flashback installation kit."

\section{References}

Alwasilah, A. Chaedar. 2001. Language, culture, and education: a portrait of contemporary Indonesia. Bandung: Andira.

Alwasilah, A Chaedar. 2002. Pokoknya Kualitatif. Jakarta, Bandung: PT Kiblat Buku Utama.

Alwasilah, A. Chaedar and Alwasilah, Senny Suzanna. 2005.

Pokoknya Menulis. Bandung 40264. PT Kiblat Buku Utama.

Axelrod, Rise B. and Charles R.

Cooper. 1988. The St. Marthin's Guide to writing. New York: St. Martin's Press.

Axelrod, Rise B. and Charles R. Cooper. 1998. The St. Marthin's Guide to writing. New York: St. Martin's Press.

Callaghan, M. 1989. A Brief Introduction to Genre. Erskineville, NSW: Metropolitan East Disadvantaged School's Program. 
Callaghan, M and Rothery, G. 1993.

The Power of Literacy.

Erskineville, NSW:

Metropolitan East

Disadvantaged School's

Program.

Callaghan, M. P. Knapp., and G. Noble. (1993). Genre in Practice. In B. Cope and M. Kalantzis (Eds.), The Powers of Literacy: A Genre Approach to Teaching Writing, pp. 179- 202. London: The Falmer Press.

Christie, F. (1992). Preparation of Teachers for Teaching English Literacy: What Constitutes Essential Knowledge? In N. Bird and J. Harris (Eds.), Quilt and Quill: Achieving and Maintaining Quality in Language Teaching and Learning, pp.222-239. Hongkong: Institute of Language in Education.

Cope, Bill and Kalantzis, Mary. 1993. The Power of Literacy: A Genre Approach to Teaching Writing. London, Washington, DC: The Falmer Press.

Departemen Pendidikan Nasional Republik Indonesia. (2001). Program Pembangunan Nasional (PROPENAS):Pembangunan Pendidikan. Retrieved 22 May, 2001 from http:// www. pdk. go.id/ program.htm.

Eggins, Suzanne. (1994). An Introduction to Systemic Functional Linguistics. London and New York: Continum.

Feez, Susan. and Joyce, Helen. (1998). Text-Based Syllabus Design.
Sydney: National Center for English Language Teaching.

Feez, Susan and Joyce, Helen. 1998. Writing Skills: Narrative \& NonFiction Text Types. Australia: Phoenix Education Pty Ltd.

Fox, Richard. 1993. Teachers Taking about Writing at Key Stage 2. Reading Journal ed. July 1993. School of Education. University of Exerter, EXI.

Gardener, Sue. 1995. "Learning to Write as an Adult". In DEAKIN University for ELL626. 1995. Literacies and Education: Writing. Australia: Deakin University.

Gibson, Joanna. 2002. Perspectives: Case studies for readers and writers. New York: Longman.

Gibbons, P. (2001). Learning a New Register in a Second Language. In C. Candlin and N. Mercer (Eds.), English Teaching in Its Social Context: A Reader, pp. 258-270. London: Routledge.

Gibbons, P. (2002). Scaffolding Language, Scaffolding Learning: Teaching Second Language Learners in the Mainstream Classroom. Portsmouth, NH: Heinemann.

Hacker, Diana. 2003. A writer's reference. Boston: Bedford/St. Martin's.

Hammond, J. (1990). Is learning to read and write the same as learning to speak?. In F. Christie (Ed.), Literacy for a Changing World, pp.26-53. Australia: ACER. 
Hammond, J. (2001). Scaffolding and Language. In J. Hammond (Ed.), Scaffolding: Teaching and Learning in Language and Literacy, pp.15-30. Education. Sydney: Primary English Teaching Association., pp.

Martin, J.R. (1999). Mentoring semogenesis: 'genre-based' literacy pedagogy. In F. Christie (Ed.), Pedagogy and the Shaping of Consciousness: Linguistic and Social Processes, pp. 123-155. London: Cassell.

Moon, Elizabeth. 1998. How to identify the dread writer's block and its relatives. Available at http://www.sff.net/people/Elizab eth.Moon/block.htm

Murray, Donald M. 2004. The craft of revision. Boston: Thomson Heinle.

Parris, Trevor B. 2001. Writing Process. Available at http://viaccess.net/tparris/ home/eng.100/waprocess.html (January 21, 2001).

Rasyid, Fathor. 1999. Teaching Argumentative Writing Through Cooperative Learning. Unpublished Master Thesis. English Education Program, Post Graduate Program. IKIP Malang.

Pusat Kurikulum- Badan Penelitian dan Pengembangan Departemen Pendidikan Nasional. (2001). Kurikulum Berbasis Kompetensi: Mata Pelajaran bahasa Inggris Sekolah Menengah Umum. Jakarta: Departemen pendidikan Nasional.
Ronk, Thom. 2003. Essay writing: stepby-step. New York: Simon and Schuster.

Saraka. 1988. From Paragraph to Essay. Concepts and Practices. Departemen Pendidikan dan Kebudayaan, Direktorat Jendral Pendidikan Tinggi, P2LPTK. Jakarta.

Smith, Quade. 1995. Students writers at work: and in the company of other writers. New York: St. Martin.

Suyanto, K. (2001). Pengembangan Kurikulum Bahasa Indonesia . Jurnal Pendidikan, 6 THN XXVIII, pp. 26-33 